\title{
Ocean Acidification Does Not Affect Fish Ectoparasite Survival
}

\author{
José Ricardo Paula ${ }^{1, *,+} \mathbb{0}$, Eve Otjacques ${ }^{1, *, \dagger}$, Courtney Hildebrandt ${ }^{2} \mathbb{D}$, Alexandra S. Grutter ${ }^{3}$ \\ and Rui Rosa ${ }^{1}$ \\ 1 MARE-Marine and Environmental Sciences Centre, Laboratório Marítimo da Guia, Faculdade de Ciências \\ da Universidade de Lisboa, Av. Nossa Senhora do Cabo, 939, 2750-374 Cascais, Portugal; rrosa@fc.ul.pt \\ 2 School of Earth, Atmospheric and Life Sciences, University of Wollongong, Wollongong, NSW 2522, \\ Australia; cah832@uowmail.edu.au \\ 3 School of Biological Sciences, The University of Queensland, St. Lucia, QLD 4072, Australia; \\ a.grutter@uq.edu.au \\ * Correspondence: jrpaula@fc.ul.pt (J.R.P.); ebotjacques@fc.ul.pt (E.O.) \\ + J.R.P. and E.O. contributed equally to this work.
}

Received: 23 January 2020; Accepted: 14 February 2020; Published: 18 February 2020

\begin{abstract}
The juveniles of gnathiid isopods are one of the most common fish ectoparasites in marine habitats and cause deleterious effects on fish by feeding on host blood and lymph. Reef fishes tend to engage in cooperative interactions with cleaning organisms to reduce their ectoparasite load. Ocean acidification (OA) pose multiple threats to marine life. Recently, OA was found to disrupt cleaner fish behaviour in mutualistic cleaning interactions. However, the potential effects of ocean acidification on this common ectoparasite remains unknown. Here, we test if exposure to an acidification scenario predicted by IPCC to the end of the century (RCP 8.5 - $980 \mu \mathrm{atm} \mathrm{pCO}_{2}$ ) affects gnathiid survival. Our results show that ocean acidification did not have any effects on gnathiid survival rate during all three juvenile life stages. Thus, we advocate that the need for cleaning interactions will persist in potentially acidified coral reefs. Nevertheless, to better understand gnathiid resilience to ocean acidification, future studies are needed to evaluate ocean acidification impacts on gnathiid reproduction and physiology as well as host-parasite interactions.
\end{abstract}

Keywords: $\mathrm{CO}_{2}$; environmental change; cleaning symbiosis; gnathiids; isopods; coral reefs

\section{Introduction}

Human-induced environmental changes currently represent the single greatest threat to global diversity. Earth's atmospheric concentration of carbon dioxide $\left(\mathrm{CO}_{2}\right)$ has been increasing at an unparalleled rate. Currently, 30\% of the anthropologically emitted $\mathrm{CO}_{2}$ is being dissolved into the ocean, which has decreased seawater $\mathrm{pH}$ by 0.1 units during the last decade [1]. When $\mathrm{CO}_{2}$ is dissolved in seawater, $\mathrm{CO}_{2}$ concentration increases and combines with water to produce carbonic acid $\left(\mathrm{H}_{2} \mathrm{CO}_{3}\right)$; this dissociates into bicarbonate $\left(\mathrm{HCO}_{3}{ }^{-}\right)$and hydrogen ions decreasing seawater $\mathrm{pH}$. The increased concentration of hydrogen ions can also interact with carbonate ions $\left(\mathrm{CO}_{3}{ }^{2-}\right)$ to form more bicarbonate, reducing the saturation of seawater aragonite and calcite, crucial for shells and skeletons of marine organisms. This phenomenon, known as ocean acidification (OA), is projected to decrease seawater $\mathrm{pH}$ between $0.14-0.42$ units by the end of this century [1,2].

Different biological responses to OA have been observed across multiple taxa, with sensitivity varying according to the measured trait, life stage, species and exposure duration [3]. OA is known to affect growth, survival, reproduction and behaviour of multiple species. In coral reefs, calcification is one of the most critical functions to be affected by OA. Lower calcification rates in corals under 
OA can result in slower coral growth and more fragile structures, making corals more susceptible to disturbances [4]. OA can also lead to the reduced abundance of crustose coralline algae, crucial to larval recruitment of invertebrates [5] and reduce zooplankton community biomass [6].

Although coral reef fish can regulate their acid-balance [7], coral reef fishes have been suggested to be susceptible to physiological and behavioural alterations under OA [7-9], yet, recent studies have also documented low or no effect of OA on fish behaviour [10-12], suggesting at least variability in fish behavioural responses to OA. During cleaning interactions, cleaner fishes inspect the body of their clients for ectoparasites, dead tissue and mucus [13]. Recently, Paula et al. (2019) [14] described a loss in motivation in cleaner wrasse Labroides dimidiatus (the most abundant cleaner fish species in the Indo-Pacific [15]) to interact with a client reef species.

Gnathiid isopods (family: Gnathiidae) are the most common ectoparasites found on coral reef fishes [16], and they can lower blood volume of their host, cause tissue damage, transmit blood-borne protozoan parasites and, in large numbers, can even cause death to adult fish $[17,18]$. Fish larvae and juveniles are especially vulnerable to the effects of ectoparasite infection, as they are small relative to the parasite, and can experience reduced performance and even mortality when infected $[18,19]$. Cleaning interactions can significantly lower the gnathiid loads on fish [20] and can indirectly affect gnathiid populations [21]. When not feeding on hosts, these ectoparasites are part of the demersal zooplankton community [22].

Nevertheless, despite the effects of OA on cleaner fish motivation and the ecological relevance of gnathiid ectoparasites, until now, the effect of $\mathrm{OA}$ on gnathiids has not been tested. To understand the effects of OA on gnathiids, we tested whether the survival rate of a cultured gnathiid species, Gnathia aureamaculosa, is altered when exposed to projected OA conditions ( 980 $\mu \mathrm{atm} \mathrm{pCO}_{2}, \mathrm{RCP} 8.02100$, in IPCC 2013 [1]).

\section{Materials and Methods}

\subsection{Parasite Culture and Gnathiid Collection}

Gnathiids G. aureamaculosa were obtained during February 6-10, 2019 from a parasite culture maintained at Lizard Island Research Station (Lizard Island, Australia $14^{\circ} 40^{\prime} \mathrm{S}, 145^{\circ} 28^{\prime} \mathrm{E}$ ) since 2001 [23,24]. Gnathiids were collected in the morning (ranging from $n=32-142$ per day, total $n$ $=510$ ) by moving a black tray around the culture tank to simulate the movement of a host. Gnathiids are briefly attracted to the tray, allowing them to more easily be captured using a pipette. Following collection, gnathiids were placed together into $75 \mathrm{~mL}$ containers filled with seawater. From these, they were individually transferred into $5 \mathrm{~mL}$ labelled vials that were half-filled with pre-conditioned seawater according to treatment (see below). Vials were held underwater in plastic baskets $(17 \times 17$ $\times 10 \mathrm{~cm}$ ), one for each treatment and replicate. The vials were randomly allocated to the seawater treatment and system replicate $\left(\mathrm{n}=510\right.$ vials; 6 baskets: $2 \mathrm{CO}_{2}$ treatments $\times 3$ replicates). Vial lids were only labelled with the combination of one letter (I, K, L, M, O or X) and one number (from 1 to 100). Thus, the experimenter was blind to the treatment, eliminating any potential observer bias. Baskets had four mesh $\left(1 \mathrm{~mm}^{2}\right)$ windows $(12 \times 5 \mathrm{~cm})$ on the sides and one in the lid $(12 \times 12 \mathrm{~cm})$ to allow water flow. A dive weight was used to submerge the baskets in experimental tanks.

\subsection{Seawater $\mathrm{CO}_{2}$ Manipulation and Aquatic Systems}

Gnathiids were maintained in a closed vial, half full of seawater with one of two treatments, control $\left(\sim 405 \mu \mathrm{atm} \mathrm{pCO}_{2}\right)$ or OA/high $\mathrm{CO}_{2}\left(\sim 980 \mu \mathrm{atm} \mathrm{pCO}_{2}\right)$. For each treatment, seawater was collected from established flow-through aquatic systems $(n=6 ; 2$ treatments $\times 3$ replicates) to maintain correct levels of total alkalinity, dissolved inorganic carbon and $\mathrm{pH}$. In these systems, natural seawater was pumped from the sea into three $10 \mathrm{~m}^{3}$ seawater storage tanks. From the storage tanks, seawater was supplied to a mixing tank and experimental tank. $\mathrm{pCO}_{2}$ control was performed indirectly by adjusting $\mathrm{pH}$ to a nominal $\mathrm{pH}$ value defined by CO2SYS software using measured salinity, total 
alkalinity, temperature and desired $\mathrm{pCO}_{2}$ as input variables. Levels of $\mathrm{pH}$ were monitored and automatically adjusted by a control unit (Profilux 3.1N, GLH, Rheinland-Pfalz, Germany), that was downregulated by direct injection of $\mathrm{CO}_{2}$ gas (BOC, North Ryde, Australia) and upregulated through aeration with atmospheric air in mixing tanks. Seawater temperature was maintained at a level similar to current reef temperature, due to the flow of recently captured seawater. Before adding water to the vial, we used handheld equipment to complement the automatic systems and measured seawater temperature (Hanna CheckTemp 1C, Woonsocket, RI, USA), salinity (V2 refractometer, TMC, Lisbon, Portugal) and $\mathrm{pH}$ (VWR pHenomenal $\mathrm{pH} 1100 \mathrm{H}$, connected to a glass electrode calibrated with TRIS- $\mathrm{HCl}$ and 2-aminopyridine- $\mathrm{HCl}$ buffers). Seawater carbonate parameters were calculated from total alkalinity (titration) and $\mathrm{pH}$ measurements. Bicarbonate and $\mathrm{pCO}_{2}$ values were calculated using CO2SYS software. Seawater parameters are summarised in Table S1.

\subsection{Gnathiid Survival and Stage Determination}

Gnathiid survival was checked daily by direct observation under a microscope (Zeiss Olympus, Munich, Germany) through the unopened clear vial, until they were identified as dead. Each basket was removed from the experimental tank, placed in an insulated container with treatment seawater to maintain temperature and transported to the microscope room. Gnathiid death was confirmed by prolonged complete cessation of any movement (from swimming to movements of body parts) after a gentle shake, or signs of body decomposition. When death was confirmed, $4 \%$ of formalin was added to the vial for further determination of the larval stage. This was determined by measuring the headwidth (HW) of fixed gnathiids, where stage one had $\mathrm{HW}<0.2 \mathrm{~mm}$, stage two $0.2 \mathrm{~mm}<\mathrm{HW}<$ $0.248 \mathrm{~mm}$ and stage three HW $>0.248 \mathrm{~mm}$ [25]. From the total of 510 gnathiids collected we discarded 35 that had an engorged gut to avoid confounding effects of feeding in our experiments. From the total of 475 gnathiids used, 260 were stage one, 177 stage two and 34 stage three.

\subsection{Statistical Analysis}

Since we have time-to-event data, we performed a survival analysis to compare the number of days alive according to $\mathrm{CO}_{2}$ treatment and gnathiid stage. We used a proportional hazards $\mathrm{Cox}$ mixed-effects model fit by maximum likelihood with $\mathrm{CO}_{2}$ treatment and gnathiid stage as categorical fixed effects, tank as a random factor and gnathiid headwidth as a covariate. Both headwidth and stage were maintained in the model as headwidth varies within stage [25], thus survival could also vary within stage. Both models with and without headwidth were fitted, yet only the full model complied with the assumption of proportional hazards (see Figures S1 and S2). We used the function "coxme" in the package "Coxme" [26] and function "Anova" in the package "Car" [27]. We verified compliance with the assumption of proportional hazards using the global test statistic in the function "coxph" from the R package "survival" [26] and graphically using a smoothed spline plot of the Schoenfeld residuals relative to time. Survival curves were plotted as Kaplan-Meier plots using the function "ggsurvplot" from the R package "survminer" [28]. Both statistical analysis and graphs were performed in R, version 3.4.3 [29].

\subsection{Ethics}

All applicable national laws and institutional guidelines for animal testing, animal care and use of animals were followed by the authors.

\section{Results}

The total number of gnathiids used per stage was distributed relatively evenly within $\mathrm{CO}_{2}$ treatments (control and high $\mathrm{CO}_{2}$, stage one: 124, 136; stage two: 95, 82; stage three: 12, 22). Survival rate was significantly different according to an interaction between headwidth and stage $\left(\chi^{2}=11.63\right.$; d.f. $=2 ; p=0.003$, Table 1; Table S2). Larger gnathiids within each stage and older gnathiids (stage 
$3>$ stage $2>$ stage 1 ) had higher survival rate. Survival rate was not significantly affected by $\mathrm{CO}_{2}$ treatment $\left(\chi^{2}=3.29\right.$; d.f. $=1 ; p=0.07$ Table 1 , Figure 1$)$.

Table 1. Analysis of deviance table (Type II tests) of gnathiid survival among $\mathrm{CO}_{2}$ treatments, gnathiid stages and size for Cox mixed effect model.

\begin{tabular}{cccc}
\hline & D.f. & $\chi^{2}$ & $p$ \\
\hline $\mathrm{CO}_{2}$ treatment & 1 & 3.29 & 0.070 \\
Larval stage & 2 & 6.35 & $\mathbf{0 . 0 4 2}$ \\
Headwidth & 1 & 27.35 & $<\mathbf{0 . 0 0 1}$ \\
$\mathrm{CO}_{2}$ treatment $\times$ Headwidth & 1 & 2.10 & 0.147 \\
$\mathrm{CO}_{2}$ treatment $\times$ Larval stage & 2 & 1.18 & 0.555 \\
Stage $\times$ Headwidth & 2 & 11.63 & $\mathbf{0 . 0 0 3}$ \\
$\mathrm{CO}_{2}$ treatment $\times$ Stage $\times$ Headwidth & 2 & 0.80 & 0.680 \\
\hline
\end{tabular}

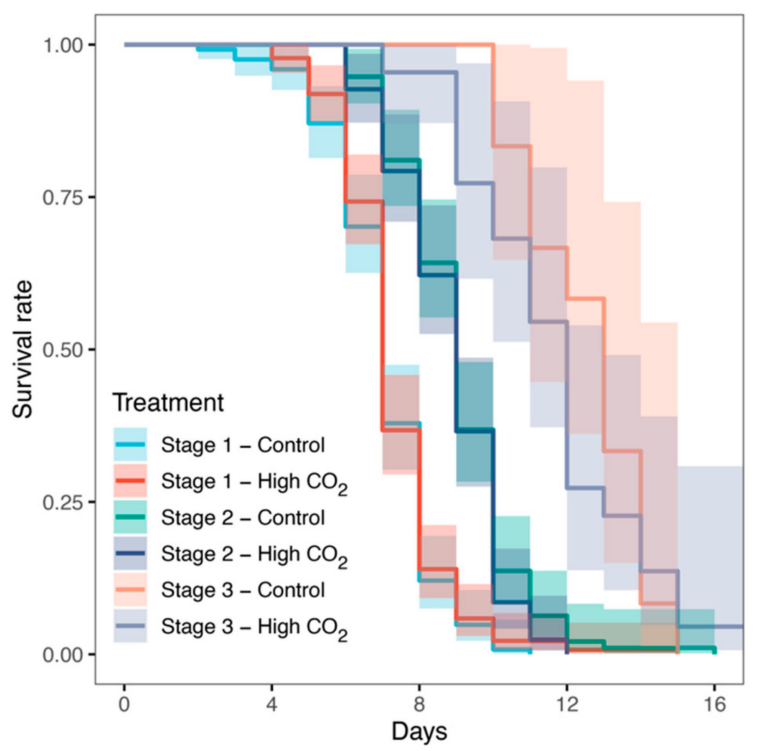

Figure 1. Effects of $\mathrm{CO}_{2}$ treatment and larval stage on gnathiid survival rate according to treatment exposure day. Survival was verified every $24 \mathrm{~h}$. Kaplan-Meier survival trajectories illustrate the different survival trajectories according gnathiid stage and $\mathrm{CO}_{2}$ treatment. Lines represent rate of live gnathiids at each exposure day. Shaded areas are $95 \%$ confidence intervals.

\section{Discussion}

OA has the potential to reduce the abundance of demersal zooplankton that reside in tropical coral reefs [6]. However, in our study, we did not observe an effect of OA on the short-term survival of the gnathiid G. aureamaculosa, an organism that forms part of the tropical reef demersal zooplankton community. Since all gnathiids considered here were not fed (i.e., no potential host was provided), all gnathiids reached death during this study most likely due to starvation. Our results indicate that, although survival was dependent on larval stage and on headwidth within a larval stage, gnathiid survival was not significantly affected by OA. Overall, there was a non-significant tendency for third stages to survive longer, with $50 \%$ of individuals surviving after 12 to 13 days, compared with 7 and 9 days for stage one and two, respectively (Figure 1). The gnathiid survival increase with age might be related to different resource allocation, as, for example, third stage gnathiids have to allocate resources to prepare reproductive organs [25]. Moreover, gnathiid survival increases with size and varies with age (AS Grutter personal communication), however this response could have varied if gnathiids were fed.

Determining which species are sensitive to $\mathrm{OA}$ is crucial to determine the impacts of $\mathrm{OA}$ on ecosystem function $[30,31]$. Previous studies have shown that extreme OA $\left(2380 \mu \mathrm{atm} \mathrm{pCO}_{2}\right)$ has 
little to no impact on the survival of non-calcifying zooplankton species, such as copepods [32]. However, in a naturally acidified reef, Smith et al. (2016) [6] observed a loss of reef-associated demersal zooplankton abundance, including zooplankton from the Order Isopoda, without any shift in diversity. The authors suggested that although this loss could be driven by: (i) an indirect effect of physiological or behavioural impacts of $\mathrm{OA}$, and (ii) reduced habitat complexity (i.e., higher abundance of branching corals at control sites, compared to a domination of massive bouldering corals in high $\mathrm{CO}_{2}$ sites). Although, in the case of gnathiids, loss of habitat complexity can be beneficial since a previous study demonstrated that gnathiids (Gnathia marleyi) prefer less complex habitats [33].

During our study, gnathiids were isolated in small vials and left to starve. We cannot ignore that potential OA effects on gnathiid physiology, digestion or behaviour (e.g., host detection and attachment success) could have indirect effects on gnathiid survival. OA can induce alterations of stomach $\mathrm{pH}$ in marine invertebrates leading to decreased digestive efficiencies [34]. Other studies also showed that host-parasite dynamics can vary with OA. Namely, increased infection rates of trematodes (Maritrema novaezealandensis) in amphipods have been described under severe acidification ( $\mathrm{pH} 7.4$ $\sim 1980 \mathrm{pCO}_{2}, 2300$ scenario) [35]. Contrarily, no effects were observed in infection rates of Perkinsus marinus in Crassostrea virginica [36]. Moreover, exposure to ocean acidification decreased cercarial survival of four parasite species (M. novazelandensis, Philophthalmus sp., Parorchis sp., and Galactosum sp.) [37]. Thus, further studies are necessary to understand hosts' susceptibility to gnathiids and the attachment success of gnathiids onto hosts, as well as the biological interactions in other parasite systems under OA.

Environmental perturbations, such as bleaching and cyclones, can lower cleaner fish abundance considerably [38] and OA has the potential to disrupt cleaning interactions [14]. Such perturbations could lead to disruptions in cleaners' control of gnathiid abundances [39]. Our results, indicating an apparent tolerance of these fish ectoparasites to OA, suggest that a potential cascading impact of OA on the cleaning symbiosis may include the continued need for cleaners' parasite removal services in clients under projected OA conditions.

Supplementary Materials: The following are available online at http:/www.mdpi.com/2673-1924/1/1/3/s1, Table S1: Seawater physicochemical parameters in all experimental setups. Table S2: Summary output for Cox mixed effects model of gnathiid survival among $\mathrm{CO}_{2}$ treatments, gnathiid stage and headwidth; Figure S1: Smoothed spline plots of Shoenfeld residuals for the Cox mixed effects model relative to time; Figure S2: Smoothed spline plots of Schoenfeld residuals of the Final Cox mixed effects model relative to time (with headwidth).

Author Contributions: Conceptualization, J.R.P., E.O., R.R and A.S.G.; methodology, J.R.P., E.O., R.R and A.S.G; validation, J.R.P., E.O., R.R and A.S.G; formal analysis, J.R.P., E.O. and A.S.G.; investigation, J.R.P., E.O. and C.H.; resources, J.R.P., A.S.G and R.R.; data curation, J.R.P., E.O. and C.H.; writing-original draft preparation, J.R.P. and E.O.; writing-review and editing, J.R.P., E.O., C.H. R.R and A.S.G.; visualization, J.R.P., E.O. and A.S.G.; supervision, A.S.G and R.R.; project administration, J.R.P and R.R.; funding acquisition, J.R.P. and R.R.. J.R.P and E.O. contributed equally to this work. All authors have read and agreed to the published version of the manuscript.

Funding: This research was funded by FCT - Fundação para a Ciência e Tecnologia, grant number PTDC/MAR-EST/5880/2014 (Project MUTUALCHANGE), grant number SFRH/BD/111153/2015 and grant number UID/MAR/04292/2013. This project was also funded by Lizard Island Reef Research Foundation, through a Lizard Island Doctoral Fellowship to J.R.P.

Acknowledgments: The authors acknowledge the staff of Lizard Island Research Station and Claudio Brandão for their help during this study.

Conflicts of Interest: The authors declare no conflict of interest.

Data Availability: The datasets generated and analysed during this study are available in the Figshare repository, doi: 10.6084/m9.figshare.11354063.

\section{References}

1. IPCC Climate Change 2013: The physical science basis contribution of working group $i$ to the fifth assessment report of the Intergovernmental Panel on Climate Change; Stocker, T.F.; Qin, D.; Plattner, G.K.; Tignor, M.; Allen, S.K.; Boschung, J.; Nauels, A.; Xia, Y.; Bex, V.; Midgley, P.M. (Eds.) Cambridge University Press: Cambridge, UK; New York, NY, USA, 2013. [CrossRef] 
2. Dupont, S.; Pörtner, H. Get ready for ocean acidification. Nature 2013, 489, 429. [CrossRef] [PubMed]

3. Kroeker, K.J.; Kordas, R.L.; Crim, R.N.; Singh, G.G. Meta-analysis reveals negative yet variable effects of ocean acidification on marine organisms. Ecol. Lett. 2010, 13, 1419-1434. [CrossRef] [PubMed]

4. Anthony, K.R.N. Coral reefs under climate change and ocean acidification: challenges and opportunities for management and policy. Annu. Rev. Environ. Resour. 2016, 41, 59-81. [CrossRef]

5. Kuffner, I.B.; Andersson, A.J.; Jokiel, P.L.; Rodgers, K.S.; MacKenzie, F.T. Decreased abundance of crustose coralline algae due to ocean acidification. Nat. Geosci. 2008, 1, 114-117. [CrossRef]

6. Smith, J.N.; De'Ath, G.; Richter, C.; Cornils, A.; Hall-Spencer, J.M.; Fabricius, K.E. Ocean acidification reduces demersal zooplankton that reside in tropical coral reefs. Nat. Clim. Chang. 2016, 6, 1124-1129. [CrossRef]

7. Heuer, R.M.; Grosell, M. Physiological impacts of elevated carbon dioxide and ocean acidification on fish. Am. J. Physiol. - Regul. Integr. Comp. Physiol. 2014, 307, R1061-R1084. [CrossRef]

8. Munday, P.L.; Jones, G.P.; Pratchett, M.S.; Williams, A.J. Climate change and the future for coral reef fishes. Fish Fish. 2008, 9, 261-285. [CrossRef]

9. Munday, P.L.; Cheal, A.J.; Dixson, D.L.; Rummer, J.L.; Fabricius, K.E. Behavioural impairment in reef fishes caused by ocean acidification at $\mathrm{CO}_{2}$ seeps. Nat. Clim. Chang. 2014, 4, 487-492. [CrossRef]

10. Clark, T.D.; Raby, G.D.; Roche, D.G.; Binning, S.A.; Speers-roesch, B.; Jutfelt, F.; Sundin, J. Ocean acidification does not impair the behaviour of coral reef fishes. Nature 2020, 577, 370-375. [CrossRef]

11. Raby, G.D.; Sundin, J.; Jutfelt, F.; Cooke, S.J.; Clark, T.D. Exposure to elevated carbon dioxide does not impair short-term swimming behaviour or shelter-seeking in a predatory coral-reef fish. J. Fish Biol. 2018, 93, 138-142. [CrossRef]

12. Sundin, J.; Amcoff, M.; Mateos-González, F.; Raby, G.D.; Jutfelt, F.; Clark, T.D. Long-term exposure to elevated carbon dioxide does not alter activity levels of a coral reef fish in response to predator chemical cues. Behav. Ecol. Sociobiol. 2017, 71, 108. [CrossRef] [PubMed]

13. Vaughan, D.B.; Grutter, A.S.; Costello, M.J.; Hutson, K.S. Cleaner fishes and shrimp diversity and a re-evaluation of cleaning symbioses. Fish Fish. 2017, 18, 698-716. [CrossRef]

14. Paula, J.R.; Repolho, T.; Pegado, M.R.; Thörnqvist, P.O.; Bispo, R.; Winberg, S.; Munday, P.L.; Rosa, R. Neurobiological and behavioural responses of cleaning mutualisms to ocean warming and acidification. Sci. Rep. 2019, 9, 12728. [CrossRef]

15. Quimbayo, J.P.; Cantor, M.; Dias, M.S.; Grutter, A.S.; Gingins, S.; Becker, J.H.A.; Floeter, S.R. The global structure of marine cleaning mutualistic networks. Glob. Ecol. Biogeogr. 2018, 27, 1238-1250. [CrossRef]

16. Grutter, A.; Poulin, R. Intraspecific and interspecific relationships between host size and the abundance of parasitic larval gnathiid isopods on coral reef fishes. Mar. Ecol. Prog. Ser. 1998, 164, 263-271. [CrossRef]

17. Sikkel, P.C.; Welicky, R.L. The ecological significance of parasitic crustaceans. In Parasitic Crustacea, Zoological Monographs; Smit, N., Bruce, N., Hadfield, K., Eds.; Springer: Cham, Switzerland, 2019; Volume 3, pp. 421-477.

18. Grutter, A.S.; Blomberg, S.P.; Fargher, B.; Kuris, A.M.; McCormick, M.I.; Warner, R.R. Size-related mortality due to gnathiid isopod micropredation correlates with settlement size in coral reef fishes. Coral Reefs 2017, 36, 549-559. [CrossRef]

19. Grutter, A.S.; Crean, A.J.; Curtis, L.M.; Kuris, A.M.; Warner, R.R.; Mccormick, M.I. Indirect effects of an ectoparasite reduce successful establishment of a damselfish at settlement. Funct. Ecol. 2011, 25, 586-594. [CrossRef]

20. Grutter, A.S. Cleaner fish really do clean. Nature 1999, 398, 672-673. [CrossRef]

21. Grutter, A.S.; Blomberg, S.P.; Box, S.; Bshary, R.; Ho, O.; Madin, E.M.P.; McClure, E.C.; Meekan, M.G.; Murphy, J.M.; Richardson, M.A.; et al. Changes in local free-living parasite populations in response to cleaner manipulation over 12 years. Oecologia 2019, 190, 783-797. [CrossRef]

22. Tanaka, K. Life history of gnathiid isopods - current knowledge and future directions. Plankt. Benthos Res. 2007, 2, 1-11. [CrossRef]

23. Hutson, K.S.; Cable, J.; Grutter, A.S.; Paziewska-Harris, A.; Barber, I. Aquatic Parasite Cultures and Their Applications. Trends Parasitol. 2018, 34, 1082-1096. [CrossRef] [PubMed]

24. Grutter, A.S. Parasite infection rather than tactile stimulation is the proximate cause of cleaning behaviour in reef fish. Proc. Biol. Sci. 2001, 268, 1361-1365. [CrossRef] [PubMed]

25. Grutter, A.S. Feeding ecology of the fish ectoparasite Gnathia sp. (Crustacea: Isopoda) from the Great Barrier Reef, and its implications for fish cleaning behaviour. Mar. Ecol. Prog. Ser. 2003, 259, 295-302. [CrossRef] 
26. Therneau, T.M.; Grambsch, P.M. Modeling Survival Data: Extending the Cox Model; Springer: New York, NY, USA, 2000.

27. Fox, J.; Weisberg, S. An r Companion to Applied Regression, 2nd ed.; SAGE Publications, Inc: Thousand Oaks, CA, USA, 2011.

28. Kassambra, A.; Kosinski, M. Survminer: drawing survival curves using "ggplot2" 2018. Available online: https://cran.r-project.org/web/packages/survminer/survminer.pdf (accessed on 25 December 2019).

29. R Core Team. R: A Language and Environment for Statistical Computing. R Found. Stat. Comput. 2018. Available online: https://www.R-project.org/ (accessed on 25 December 2019).

30. Fabry, V.J.; Seibel, B.A.; Feely, R.A.; Orr, J.C. Impacts of ocean acidification on marine fauna and ecosystem processes. ICES J. Mar. Sci. 2008, 65, 414-432. [CrossRef]

31. Melzner, F.; Mark, F.C.; Seibel, B.A.; Tomanek, L. Ocean acidification and coastal marine invertebrates: tracking $\mathrm{CO}_{2}$ effects from seawater to the cell. Ann. Rev. Mar. Sci. 2020, 12, 1-25. [CrossRef]

32. Kurihara, H.; Ishimatsu, A. Effects of high $\mathrm{CO}_{2}$ seawater on the copepod (Acartia tsuensis) through all life stages and subsequent generations. Mar. Pollut. Bull. 2008, 56, 1086-1090. [CrossRef]

33. Artim, J.M.; Sikkel, P.C. Live coral repels a common reef fish ectoparasite. Coral Reefs 2012, 32, $487-494$. [CrossRef]

34. Stumpp, M.; Hu, M.; Casties, I.; Saborowski, R.; Bleich, M.; Melzner, F.; Dupont, S. Digestion in sea urchin larvae impaired under ocean acidification. Nat. Clim. Chang. 2013, 3, 1044-1049. [CrossRef]

35. Harland, H.; MacLeod, C.D.; Poulin, R. Non-linear effects of ocean acidification on the transmission of a marine intertidal parasite. Mar. Ecol. Prog. Ser. 2015, 536, 55-64. [CrossRef]

36. Keppel, A.G.; Breitburg, D.L.; Wikfors, G.H.; Burrell, R.B.; Clark, V.M. Effects of co-varying diel-cycling hypoxia and $\mathrm{pH}$ on disease susceptibility in the eastern oyster Crassostrea virginica. Mar. Ecol. Prog. Ser. 2015, 538, 169-183. [CrossRef]

37. MacLeod, C.D.; Poulin, R. Differential tolerances to ocean acidification by parasites that share the same host. Int. J. Parasitol. 2015, 45, 485-493. [CrossRef] [PubMed]

38. Triki, Z.; Wismer, S.; Levorato, E.; Bshary, R. A decrease in the abundance and strategic sophistication of cleaner fish after environmental perturbations. Glob. Chang. Biol. 2018, 24, 481-489. [CrossRef] [PubMed]

39. Grutter, A.S.; De Brauwer, M.; Bshary, R.; Cheney, K.L.; Cribb, T.H.; Madin, E.M.P.; McClure, E.C.; Meekan, M.G.; Sun, D.; Warner, R.R.; et al. Parasite infestation increases on coral reefs without cleaner fish. Coral Reefs 2018, 37, 15-24. [CrossRef]

(C) 2020 by the authors. Licensee MDPI, Basel, Switzerland. This article is an open access article distributed under the terms and conditions of the Creative Commons Attribution (CC BY) license (http://creativecommons.org/licenses/by/4.0/). 